\title{
Coral-eating snail Drupella cornus population increases in Kenyan coral reef lagoons
}

\author{
T. R. McClanahan \\ The Wildlife Conservation Society, Coral Reef Conservation Project, PO Box 99470, Mombasa, Kenya
}

\begin{abstract}
Data from a study of corallivorous snails in 8 Kenyan coral-reef lagoons sampled at 3 time intervals over a 6 yr period suggest that Drupella cornus populations have increased on Kenyan reefs. This increase was greatest in heavily fished reefs and a transition reef (converted to a park in about 1990) but less pronounced in the unfished parks and a reserve (restricted fishing). The abundance of corallivorous snails was better predicted by the abundance of their predators than the abundance of their coral food. The 2 most abundant species, Coralliophila violacaea and $D$. cornus, were associated with the coral genus Porites although $D$. cornus was found on a wider variety of coral genera than $C$. violacea. $D$. cornus was most abundant on fished reefs with the exception of 1 reef where $C$. violacea was dominant and persisted at high population densities over the study period. Observed population increases in Kenya and western. Australia may be due to oceanic conditions which improved $D$. cornus recruitment success during the late 1980 s.
\end{abstract}

KEY WORDS: Fishing · Marine protected areas · Population dynamics · Prosobranch snails

\section{INTRODUCTION}

Benthic invertebrates such as coral-eating starfish (Moran 1986), prosobranch snails (Moyer et al. 1982, 1985, Turner 1992a), and sea urchins (Lessios et al. 1984, McClanahan \& Kurtis 1991, Glynn \& Colgan 1992) frequently exhibit periods of stability punctuated with rapid population increases and decreases. These population changes are frequently associated with major changes in the ecological structure and processes of the coral-reef ecosystem. The causes of these fluctuations in population abundance are seldom known and it is frequently asked whether humans have had an influence in these population 'outbreaks' and 'mass mortalities'. Determining the causes of these population fluctuations is often difficult due to high spatial variability in coral reefs and the lack of replicate human management 'treatments' which allow for the statistical detection of human influence apart from the frequently synergistic influences of natural events. Separating human-influenced sources of variation from the natural ones, and how they interact is, therefore, one of the major challenges of both theoretical and applied marine ecology.
Corallivorous snails such as Drupella cornus (synonymous with Morula or Drupella elata; Spry 1961, Wilson 1992), Coralliophila violacea (= C. neritoidea; Abbott \& Dance 1986) and other members of the Thaidinae and Coralliophilidae are ubiquitous members of the coral reef. Coral-reef snails are most frequently found at low population densities (i.e. < 1 per $10 \mathrm{~m}^{2}$; McClanahan 1990, McClanahan \& Muthiga 1992). However, outbreaks or exponential population increases of Drupella snails have been recorded in Japan (Moyer et al. 1982, 1985) in the period 1976 to 1980, Enewetak (Boucher 1986), and in western Australian reefs during the late 1980s until the present (Turner 1992a, 1994). At high population densities, the snails' scars, left from their feeding on living coral, can kill extensive coral areas leaving reefs to be colonized by filamentous algae. Coral mortality in some areas of Japan and Enewetak, originally attributed to Acanthaster planci feeding, was later discovered to be created by Drupella swarms, which feed at night and was, therefore, less obvious to daytime observers (Moyer et al. 1982, 1985, Boucher 1986).

The causes of these large population increases and whether they are spreading in extent and intensity are 
largely unknown. Here I report on what appears to be the initial stages of a large increase in Drupella cornus populations in Kenyan coral reef lagoons. By comparing the management history and abundance of coral and predatory fishes on studied reefs, I attempt a partial explanation of the factors which may contribute to successful $D$. cornus population outbreaks.

\section{METHODS}

Collection of data included (1) coral cover to the genus level, (2) finfish to the family level and (3) snails (prosobranch gastropods) to the species level. Complete surveys were undertaken in 6 Kenyan coral reef lagoons in 1987 and again in 1992 and 1993. Snails were surveyed in 2 additional reefs [Kisite Marine National Park (MNP) and Mpunguti Marine National Reserve (MNR)] but other field measurements were not made on these 2 reefs. Data collection followed previously described methods (McClanahan \& Muthiga 1989, McClanahan 1990, McClanahan \& Shafir 1990). Coral cover estimates are based on 9 to 2710 -m line transects per site where coral is identified to the genus.

Fish population estimates are based on 3 to 9 replicate $5 \times 100 \mathrm{~m}$ belt-transects per reef per sampling period where individuals were identified to the family and to the nearest $10 \mathrm{~cm}$ length-class interval (McClanahan \& Shafir 1990). Data are presented for members of 4 durophagous families (Balistidae, Diodontidae, Labridae and Lutjanidae) known to feed on snails and other hard-bodied invertebrates (Randall 1967, McClanahan \& Shafir 1990). Abundance of species within each family category are presented in McClanahan (in press a). Members of the 'Lutjanidae' group are actually a combination of species in the Lutjanidae, Lethrinidae and Haemulidae as taxonomically organized by Nelson (1984). The reasons for this grouping are that (1) some species in these families are difficult to distinguish in the field and (2) the family-subfamily taxonomy of these groups has been unstable in field guides (e.g. compare Carcasson 1977 with Nelson 1984).

The wet weights (i.e. $\mathrm{kg} \mathrm{ha}^{-1}$ ) of fish were calculated for each family using length-weight relationships established at a local landing site (Kenyatta Beach; McClanahan unpubl. data). Lengths and weights were taken for many individuals and species and then grouped into the above family categories for calculating length-weight relationships. From these relationships an appropriate length to weight conversion factor was applied to each family and size-class group. Biomass of each family was then estimated by summing the weight estimates in each length category.

Estimates of prosobranch population densities were made on the above 6 reefs and 2 additional protected reefs (Kisite MNP and Mpunguti MNR). All reefs are similar in being shallow $(<3 \mathrm{~m}$ at low tide) coral reef areas protected from wave exposure and dominated by hard coral and algal cover. Of these 8 study sites, 5 received some protective management. Three reefs (Malindi, Watamu and Kisite MNPs) have been successfully protected from fishing and other resource removal for over $20 \mathrm{yr}$ with infrequent poaching (author's pers. obs., Marine Park wardens pers. comm.). One reef experienced low levels of line and trap fishing (Mpunguti MNR) for over 5 yr (A. Kaka, warden, pers. comm.) Another reef, Mombasa MNP, had a history of intense fishing but was converted into a marine park in 1990, and excluded fishermen shortly thereafter. Three reefs (Diani, Kanamai and Vipingo) had a long history of exposure to fishing and shell and coral collection.

Prosobranch snails were surveyed in the 8 reefs using a time-sampling technique where the number of species and individuals of each species are tallied during a $1 \mathrm{~h}$ daylight search period. The method has been described previously in more detail (McClanahan 1989, 1992a), tested against a quadrat method, and found to be superior for species with low population densities (McClanahan \& Muthiga 1992) - common to the studied Kenyan reef lagoons (McClanahan 1990). Search sampling in the coral-reef habitat covers approximately $500 \mathrm{~m}^{2} \mathrm{~h}^{-1}$ (Kohn 1968, McClanahan \& Muthiga 1992).

Data were analyzed in 2 ways. Data from hourly samples tended to be right-skewed and, therefore, the nonparametric Mann-Whitney $U$-tests or Wilcoxon signed-rank test were used on hourly samples for comparisons with the older marine parks and the unprotected reefs. Data analysis based on hourly samples may be considered a 'pseudoreplicated' design (Hurlburt 1984). Because there are only a few marine parks and hourly samples are most frequently from different sites within individual marine parks, the scale-dependent definition of pseudoreplication is a dubious criticism of this analysis. Therefore, in addition to the above analyses, 2-way ANOVAs were performed on data using sites as the basis for replication -- based on hourly samples within each site. This design is not pseudoreplicated but suffers from the unavoidable low number of replicate $(n=3)$ older protected areas.

\section{RESULTS}

Field studies indicate a lower abundance and more diverse fauna of corallivores in protected than unprotected reefs (Table 1, Fig. 1). In 1987, Coralliophila violacea was by far the most common corallivore in the 8 studied reefs by around a factor of 70 while Drupella 
Table 1. Coral abundance, potential snail predators from durophagous fish families, and the abundance of the 2 most common coral-eating snails Drupella cornus and Coralliophila violacea in 6 of the 8 studied reef lagoons during the 3 sampling periods. Values are $\bar{x} \pm \mathrm{SE}$ (sample size). Protected reefs are indicated by the MNP after the site's name and sites are ordered from north on the left to south on the right of the table. Two protected areas not shown (Kisite and Mpunguti MNP) have low snail population densities and high fish population densities and are located to the south of Diani. UP: unprotected

\begin{tabular}{|c|c|c|c|c|c|c|}
\hline & Malindi MNP & Watamu MNP & Vipingo-UP & Kanamai-UP & Mombasa MNP & Diani-UP \\
\hline \multicolumn{7}{|l|}{ Coral cover $(\%)$} \\
\hline Jul 1987 & $17.6 \pm 3.3(15)$ & $30.0 \pm 8.2$ & $18.1 \pm 2.6(27)$ & $12.7 \pm 1.8(27)$ & $8.9 \pm 1.4(24)$ & $4.6 \pm 1.1(18)$ \\
\hline Feb 1992 & $20.8 \pm 4.0(18)$ & $29.2 \pm 3.3(12)$ & $22.0 \pm 2.5(27)$ & $17.7 \pm 2.6(27)$ & $31.1 \pm 2.4(27)$ & $6.4 \pm 1.9(18)$ \\
\hline Nov 1992 & $20.4 \pm 4.5(18)$ & $29.6 \pm 3.1(12)$ & $16.6 \pm 1.9(27)$ & $13.4 \pm 1.6(27)$ & $29.7 \pm 2.2(27)$ & $6.9 \pm 1.1(18)$ \\
\hline \multicolumn{7}{|l|}{ Predators $\left(\mathrm{kg} \mathrm{ha}^{-1}\right)$} \\
\hline Balistidae, 1988 & $31.73 \pm 15.48(5)$ & $5.26 \pm 2.54$ & $2.05 \pm 1.62(5)$ & $0.00 \pm 0.00$ & $2.09 \pm 1.62(5)$ & $1.68 \pm 1.68(5)$ \\
\hline 1992 & $22.33 \pm 6.62$ & $9.00 \pm 0.62$ & $3.35 \pm 2.05(5)$ & $2.93 \pm 2.39(5)$ & $11.89 \pm 5.68(9)$ & $0.00 \pm 0.00$ \\
\hline 1993 & $39.83 \pm 3.82$ & $40.23 \pm 15.85$ & $8.75 \pm 2.95(5)$ & $4.54 \pm 4.50(5)$ & $1.68 \pm 1.68$ & $0.00 \pm 0.00$ \\
\hline Diodontidae, 1988 & $0.00 \pm 0.00$ & $6.94 \pm 6.94$ & $4.55 \pm 2.93$ & $2.84 \pm 2.84$ & $4.17 \pm 4.17$ & $0.00 \pm 0.00$ \\
\hline 1992 & $2.84 \pm 2.84$ & $0.00 \pm 0.00$ & $1.71 \pm 1.71$ & $0.00 \pm 0.00$ & $16.57 \pm 7.67$ & $1.71 \pm 1.71$ \\
\hline 1993 & $0.78 \pm 0.78$ & $0.00 \pm 0.00$ & $1.57 \pm 0.96$ & $1.71 \pm 1.71$ & $1.71 \pm 1.71$ & $0.00 \pm 0.00$ \\
\hline Labridae, 1988 & $68.84 \pm 12.88$ & $84.48 \pm 3.90$ & $32.48 \pm 4.06$ & $11.70 \pm 2.59$ & $9.17 \pm 1.56$ & $4.11 \pm 0.85$ \\
\hline 1992 & $55.18 \pm 6.56$ & $67.53 \pm 17.94$ & $30.36 \pm 2.29$ & $21.00 \pm 2.69$ & $31.00 \pm 4.07$ & $4.81 \pm 0.86$ \\
\hline 1993 & $70.58 \pm 6.18$ & $63.37 \pm 13.34$ & $33.62 \pm 5.12$ & $19.45 \pm 1.98$ & $29.27 \pm 13.77$ & $1.82 \pm 0.32$ \\
\hline Lutjanidae, 1988 & $32.27 \pm 9.70$ & $158.76 \pm 99.07$ & $0.00 \pm 0.00$ & $0.00 \pm 0.00$ & $0.91 \pm 0.91$ & $0.00 \pm 0.00$ \\
\hline 1992 & $159.33 \pm 69.14$ & $195.71 \pm 35.12$ & $0.38 \pm 0.23$ & $0.19 \pm 0.19$ & $33.82 \pm 12.68$ & $0.93 \pm 0.90$ \\
\hline 1993 & $91.53 \pm 44.95$ & $263.66 \pm 47.12$ & $2.81 \pm 1.73$ & $22.91 \pm 9.81$ & $144.26 \pm 63.52$ & $1.21 \pm 0.59$ \\
\hline \multicolumn{7}{|c|}{ Drupella cornus (no. $\mathrm{h}^{-1}$ ) } \\
\hline 1987 & $0.00 \pm 0.00(6)$ & $0.00 \pm 0.00(5)$ & $0.00 \pm 0.00(3)$ & $0.40 \pm 0.24(6)$ & $0.00 \pm 0.00(5)$ & $0.60 \pm 0.60(5)$ \\
\hline 1992 & $3.50 \pm 0.77(4)$ & $0.00 \pm 0.00(3)$ & $3.70 \pm 2.67(3)$ & $10.80 \pm 6.72(4)$ & $8.60 \pm 3.14(5)$ & $3.00 \pm 1.15(3)$ \\
\hline 1993 & $1.00 \pm 0.00(2)$ & $1.00 \pm 1.00(2)$ & $27.00 \pm 8.00(2)$ & $6.50 \pm 2.50(2)$ & $13.80 \pm 5.03(6)$ & $6.00 \pm 4.00(2)$ \\
\hline \multicolumn{7}{|c|}{ Coralliophilia violacea (no. $\mathrm{h}^{-1}$ ) } \\
\hline 1987 & $2.16 \pm 1.38$ & $4.68 \pm 4.58$ & $3.33 \pm 3.33$ & $0.00 \pm 0.00$ & $2.00 \pm 2.00$ & $59.20 \pm 32.00$ \\
\hline 1992 & $0.00 \pm 0.00$ & $1.67 \pm 0.88$ & $0.66 \pm 0.33$ & $9.75 \pm 6.40$ & $4.60 \pm 1.63$ & $60.30 \pm 0.88$ \\
\hline 1993 & $2.00 \pm 1.00$ & $13.00 \pm 0.00$ & $8.50 \pm 0.50$ & $6.00 \pm 4.00$ & $1.50 \pm 0.56$ & $71.20 \pm 15.06$ \\
\hline
\end{tabular}

cornus was the most abundant of the uncommon Thaidinae (Tables $1 \& 2$ ). However, D. cornus populations increased by a factor of 40 between 1987 and 1992 and a factor of 75 between 1987 and 1993.

Coralliophila violacea populations doubled over the sampling period (Table 2, Fig. 1). Comparing hourly samples of $C$. violacea, over the 3 sampling periods, indicated a significant increase $(p<0.05)$ between 1987 and 1992. Comparisons based on hourly samples also indicated higher population numbers in unprotected than protected reefs. However, the protectedunprotected population differences were not statistically significant in 1993 due to the snails' patchy spatial distributions (i.e. high variation; Tables 1 \& 2).

Changes in Drupella cornus populations in Kenya's southern fringing reef lagoons did not occur in all reefs with equal intensity. Increases in the 3 marine parks (Malindi, Watamu and Kisite) and the Reserve (Mpunguti) were modest - increasing from unrecorded in 1987 to $\sim 1 \mathrm{~h}^{-1}$ in 1992 and 1993 (Table 1, Fig. 1). In contrast the unprotected reefs experienced a large increase in $D$. cornus over the sampling period, as did the reef in transition from heavy fishing to total protection (Mombasa MNP). Combining D. cornus data for all sites by years and performing a Wilcoxon signed-rank test with the hourly samples as replicates produced statistically significant differences for these temporal comparisons between 1987 and 1992 and 1993 (1987 vs 1992, $\mathrm{p}<0.003$; 1987 vs 1993, $\mathrm{p}<0.008$; 1992 vs 1993 , statistically insignificant, ns).

Table 2. Comparison of the abundance $\left(\bar{x} \pm \mathrm{SE}, \mathrm{no} . \mathrm{h}^{-1}\right)$ of the 2 most common coral-eating snails in the protected (i.e. Marine Parks, no fishing or collection) and unprotected reefs. Wilcoxon signed-rank test compares protected versus unprotected for each year. ns: not significant

\begin{tabular}{|c|c|c|c|}
\hline Year & Protected reefs & Unprotected reefs & $\mathrm{p}$ \\
\hline \multicolumn{4}{|c|}{ Drupella cornus } \\
\hline 1987 & $0.00 \pm 0.00$ & $0.38 \pm 0.23$ & ns \\
\hline 1992 & $1.27 \pm 0.60$ & $6.30 \pm 2.84$ & 0.06 \\
\hline 1993 & $0.57 \pm 0.30$ & $13.16 \pm 4.99$ & 0.03 \\
\hline \multicolumn{4}{|c|}{ Coralliophila violacea } \\
\hline 1987 & $3.13 \pm 1.30$ & $14.77 \pm 8.52$ & ns \\
\hline 1992 & $1.00 \pm 0.59$ & $22.20 \pm 8.82$ & 0.04 \\
\hline 1993 & $6.57 \pm 2.02$ & $34.00 \pm 17.84$ & ns \\
\hline
\end{tabular}


(a) Coralliophila violacea
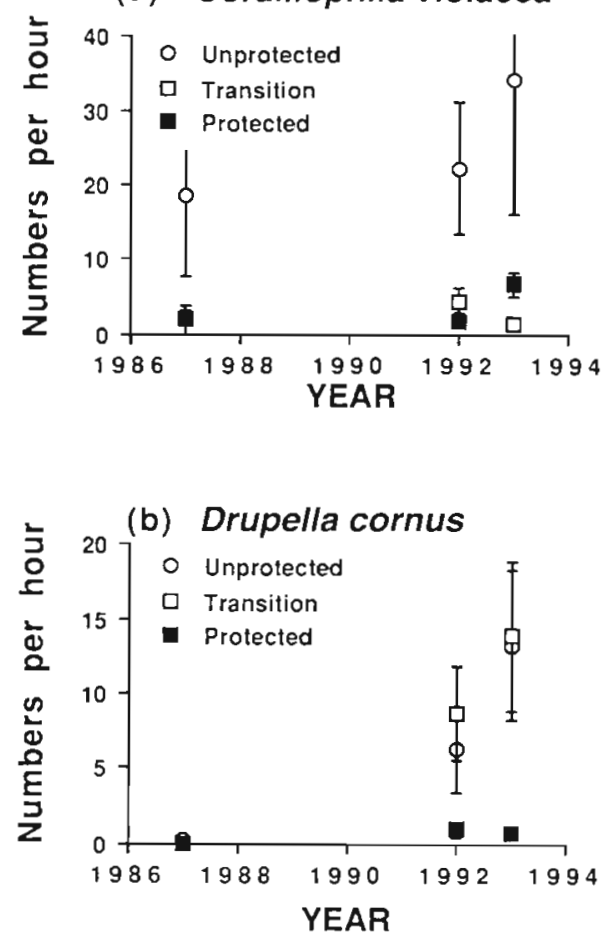

(c) other Thaidinae

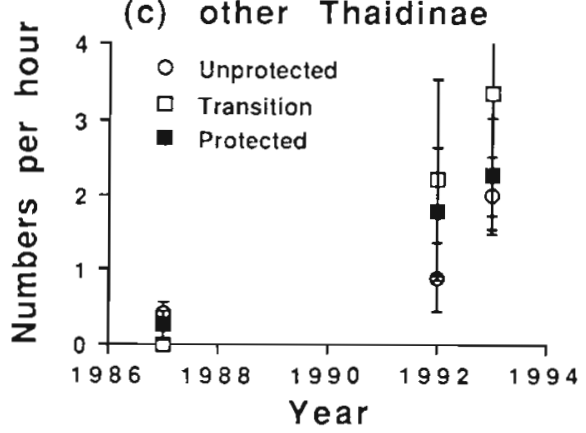

Fig. 1. Abundance $(\bar{x} \pm \mathrm{SE})$ of $(a, b)$ the 2 dominant species of coral-eating snails and (c) other members of the Thaidinae as a function of the 3 sampling intervals. Data combine reefs into 3 reef categories where unprotected reefs are reefs exposed to unregulated fishing, the transition reef is Mombasa MNP which was converted into a marine park around 1990, and protected reefs include Kenya's other 3 marine parks and the Mpunguti Marine Reserve which experiences light and controlled fishing. See Table 1 for sample sizes of reef categories and years

Comparison of Drupella cornus population estimates between protected and unprotected reefs indicated significantly higher population densities in unprotected than protected reefs in 1992 and 1993 but not in 1987. If data are combined such that the older marine parks ( $n=3$ ) and unprotected reefs $(n=3)$ are the replicates and a 2-way ANOVA, with protection
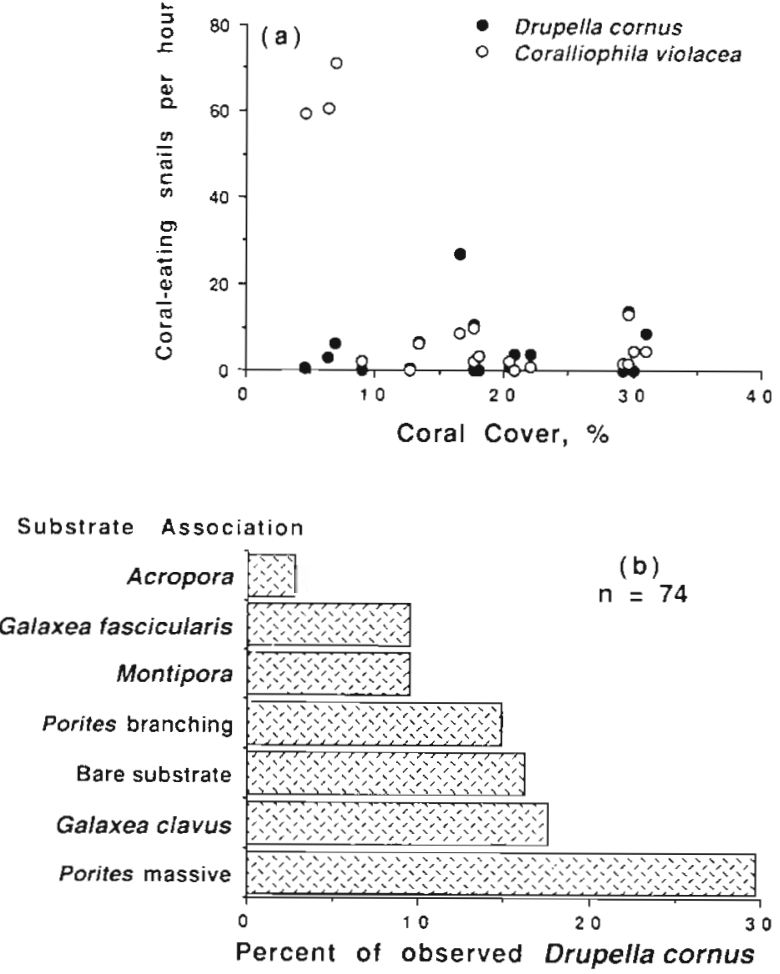

Fig. 2. (a) Abundance of coral-eating snails Drupella cornus and Coralliophila violacea as a function of coral cover in 6 studied reefs where coral cover was measured during the 3 sampling intervals $(1987,1992,1993)$. (b) Association of $D$. cornus with coral and substrate types in 3 studied reefs (Mombasa, Diani and Vipingo). C. violacea was found nearly exclusively on massive Porites

and time as the treatments, is performed, then only protection is statistically significant for $D$. cornus (at $\mathrm{p}<0.05$; Table 3). Neither time nor protection are significant predictors of population numbers at $p<0.05$ for Coralliophila violacea by the 2 -way ANOVA procedure.

Previous studies suggested that outbreaks or high population densities are most common on reefs with abundant coral (Osborne 1992). Preferred corals are reported to be from the genus Acropora and the family Pocilloporidae (Moyer et al. 1982, Boucher 1986, Ayling \& Ayling 1992, Cumming 1992, pers. comm.). However, scatterplots of the abundance of Coralliophila violacea and Drupella cornus with coral abundance (Fig. 2a) suggest no relationship $(n=0.07, n=6$ reefs $\times 3$ sampling periods $=18, \mathrm{~ns}$ ) with $D$. cornus and a negative relationship for $C$. violacea $(r=-0.63, p<0.05)$.

During a portion of the final survey I recorded the species or genus of coral on which I found Drupella cornus and Coralliophila violacea resting or feeding. C. violacea was found nearly exclusively (i.e. $>95 \%$ ) in the crevices of the massive Porites lutea or other 
Table 3. Two-way ANOVA analysis of Drupella cornus and Coralliophila violacea abundance with reef protection (using only the older marine parks, $\mathrm{n}=3$ ) and time ( 3 sampling periods) being the treatments

\begin{tabular}{|c|c|c|c|c|}
\hline Source of variation & $\mathrm{df}$ & MS & $F$ & $\mathrm{p}$ \\
\hline \multicolumn{5}{|c|}{ Drupella cornus abundance } \\
\hline Protection & 1 & 153.13 & 5.51 & 0.04 \\
\hline Time & 2 & 68.35 & 2.46 & 0.13 \\
\hline Interaction & 2 & 57.04 & 2.05 & 0.17 \\
\hline Within & 12 & 27.79 & & \\
\hline Total & 17 & & & \\
\hline \multicolumn{5}{|c|}{ Coralliophila violacea abundance } \\
\hline Protection & 1 & 1916.01 & 3.25 & 0.10 \\
\hline Time & 2 & 60.46 & 0.10 & 0.90 \\
\hline Interaction & 2 & 10.56 & 0.02 & 0.98 \\
\hline Within & 12 & 589.63 & & \\
\hline Total & 17 & & & \\
\hline
\end{tabular}

species of massive Porites with juveniles occasionally found on acroporids and branching Porites. Porites was also the single most dominant genus occupied by $D$. cornus but was also found with a greater variety of coral genera and species (Fig. 2b). However, there were no significant correlations between the abundance of corallivorous snails and the abundance of either branching or massive Porites - the $D$. cornus branching Porites relationship was just short of statistical significance $(r=0.76, p=0.07)$. However, the similar coral association among studied snail species suggests the potential for competition for food, or perhaps more importantly, competition for crevices near a food source.
Predation in these reef lagoons has been studied previously in some detail (McClanahan 1989, 1992b, McClanahan \& Muthiga 1989, McClanahan \& Shafir 1990). An analysis of fish population numbers and biomass estimates (Table 4) suggests that balistids (largely Balistapus undulatus and Rhinecanthus aculeatus) and lutjanids are significantly more abundant in protected than unprotected reefs regardless of the method of analysis. Diodontids are similar in protected and unprotected reefs while labrids have similar numbers but lower biomass in unprotected reefs.

To determine the possible effects of predation I calculated average biomasses of fish families for the 6 intensively studied sites based on the 3 sampling periods. I then plotted these biomass averages with average Coralliophila violacea population estimates for the 3 sampling periods and Drupella cornus populations for the last 2 sampling periods (Fig. 3). No relationship was found between the corallivorous snails and diodontid populations and a poor but negative relationship between the corallivorous snails and lutjanid abundance (Fig. 3c). However, C. violacea abundance appears to decrease steeply with increasing labrid and balistid abundance, whereas $D$. cornus exhibits a peak at a low to intermediate abundance of these 2 families (Fig. 3a, b).

\section{DISCUSSION}

This study presents a retrospective analysis of corallivorous snail population changes over a 6 yr period where the second most abundant snail, Drupella cornus, has experienced large population increases par-

Table 4. Comparison of the population density $(\bar{x} \pm \mathrm{SE}$ ) and biomass of members of 4 families of durophagous fish (potential snail predators) in the protected (i.e marine parks, no fishing or collection) and unprotected reefs during the 3 sampling periods

\begin{tabular}{|c|c|c|c|c|c|c|}
\hline \multirow[t]{2}{*}{ Year } & \multicolumn{3}{|c|}{ Density (no. per $500 \mathrm{~m}^{2}$ ) } & \multicolumn{3}{|c|}{ Biomass, wet wt ( $\mathrm{kg} \mathrm{ha}^{-1}$ ) } \\
\hline & Protected reefs & Unprotected reefs & $\mathrm{p}$ & Protected reefs & Unprotected reefs & $\mathrm{p}$ \\
\hline \multicolumn{7}{|c|}{ Balistidae } \\
\hline 1988 & $3.50 \pm 0.71$ & $0.23 \pm 0.12$ & 0.012 & $21.801 \pm 10.47$ & $1.43 \pm 0.86$ & 0.012 \\
\hline 1992 & $2.75 \pm 0.68$ & $0.60 \pm 0.32$ & 0.025 & $17.33 \pm 4.65$ & $2.09 \pm 1.22$ & 0.012 \\
\hline 1993 & $4.50 \pm 0.78$ & $0.47 \pm 0.22$ & 0.017 & $39.985 \pm 5.66$ & $4.4 \pm 1.92$ & 0.017 \\
\hline \multicolumn{7}{|c|}{ Diodontidae } \\
\hline 1988 & $0.13 \pm 0.13$ & $0.23 \pm 0.12$ & 1.000 & $2.60 \pm 2.60$ & $2.41 \pm 1.32$ & 0.655 \\
\hline 1992 & $0.13 \pm 0.13$ & $0.13 \pm 0.09$ & 1.000 & $1.78 \pm 1.78$ & $1.14 \pm 0.78$ & 0.655 \\
\hline 1993 & $0.13 \pm 0.13$ & $0.20 \pm 0.11$ & 1.000 & $0.49 \pm 0.49$ & $1.17 \pm 0.68$ & 1.000 \\
\hline \multicolumn{7}{|c|}{ Labridae } \\
\hline 1988 & $56.75 \pm 8.26$ & $56.46 \pm 12.86$ & 0.012 & $74.70 \pm 8.31$ & $16.78 \pm 4.00$ & 0.012 \\
\hline 1992 & $62.88 \pm 7.73$ & $74.80 \pm 10.98$ & 0.036 & $59.81 \pm 7.41$ & $18.73 \pm 3.04$ & 0.012 \\
\hline 1993 & $74.00 \pm 4.47$ & $74.87 \pm 14.96$ & 0.889 & $67.88 \pm 5.87$ & $18.30 \pm 3.87$ & 0.012 \\
\hline \multicolumn{7}{|c|}{ Lutjanidae } \\
\hline 1988 & $16.00 \pm 9.65$ & $0.00 \pm 0.00$ & 0.012 & $79.70 \pm 40.20$ & $0.00 \pm 0.00$ & 0.012 \\
\hline 1992 & $21.32 \pm 5.47$ & $0.33 \pm 0.13$ & 0.012 & $172.98 \pm 43.40$ & $0.50 \pm 0.31$ & 0.012 \\
\hline 1993 & $20.00 \pm 5.57$ & $6.67 \pm 2.39$ & 0.017 & $156.08 \pm 44.18$ & $8.98 \pm 4.06$ & 0.012 \\
\hline
\end{tabular}



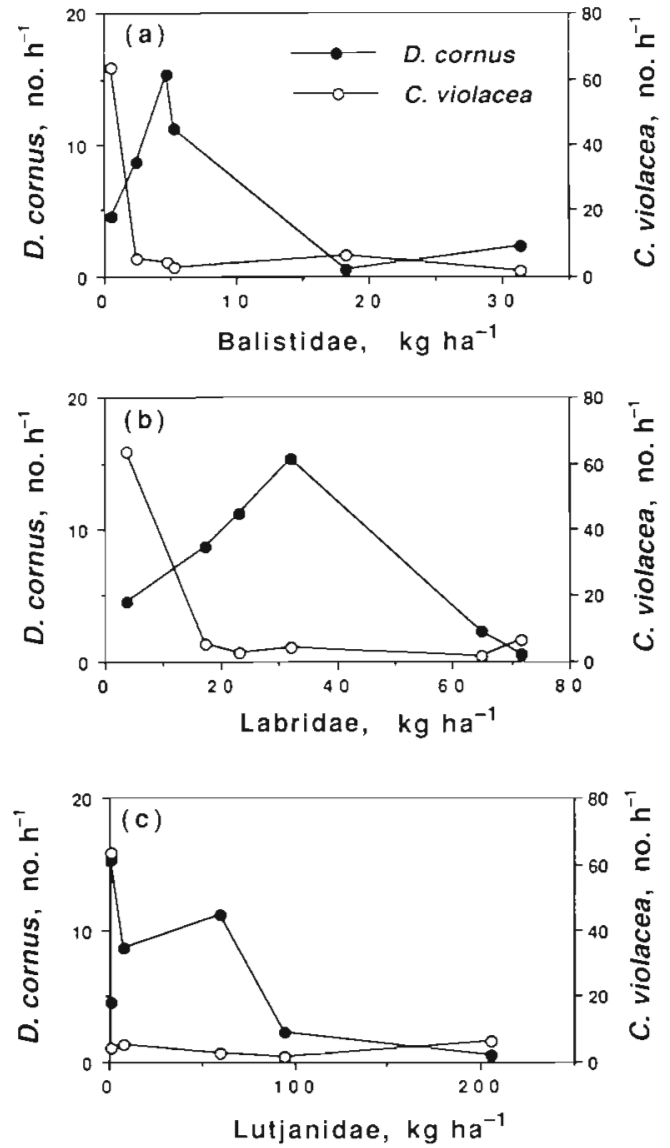

Fig. 3. Scatterplots of the abundance of coral-eating snails Drupella cornus and Coralliophila violacea as a function of (a) Balistidae (triggerfish), (b) Labridae (wrasses) and (c) the 'Lutjanidae' = Lutjanidae. Haemulidae and Lethrinidae

ticularly in 2 unprotected reefs and a reef recently closed from fishing. Populations of $D$. cornus have not reached the high levels reported in Japan and western Australia but have simply increased from a rare species to among the most abundant prosobranch species. However, the influence of $D$. cornus on living coral is largely unnoticeable, at present, and the relationship between coral and $D$. cornus abundance is weak (i.e. branching Porites) to nonexistent (total coral cover) at the given level of sampling. Heavily fished reefs, with the lowest fish biomass, have a coral assemblage largely composed of massive and branching Porites (McClanahan \& Mutere 1994) and Coralliophila violacea appears to be the most successful species under these conditions. $D$. cornus is most abundant at low to intermediate predator abundance and is associated with more diverse coral assemblages.

Existing correlational data and the experimental conditions of fished and unfished reefs would suggest that high Drupella cornus populations may be affected by the abundance of the invertebrate predator guild such as balistids (i.e. Balistapus undulatus) and perhaps some species of labrids (McClanahan in press b). Yet, unless further experimental studies are completed and the possibility of other factors associated with low predator abundance are discounted, this conclusion remains tentative.

Is this population change in Drupella cornus, over the 6 yr of study, part of a population expansion from western Australia (Turner 1992a), a cyclic pattern compounded by human influences, a result of increasing eutrophication of nearshore waters (Moyer et al. 1982), or the long-term consequence of overfishing (Aronson 1990)? The nearshore eutrophication hypothesis is not supported by the Kenya, Enewetak or western Australia observations and data (Boucher 1986, Turner 1992a, 1994). In Kenya, Malindi reef waters were col-

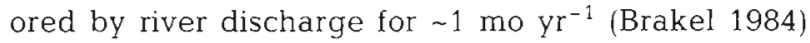
but have maintained low $D$. cornus populations over the study period. The cyclic pattern may be supported by the coincidence between population increases and peak sunspot activity and heating of Indo-Pacific waters in 1987 (Yan et al. 1992). Reported population increases in western Australia and Kenya have occurred during a similar time and may be part of a similar response to global oceanic conditions. Alternatively, population increases in Kenya may be an expansion of large populations from western Australia. However, larval development of $D$. cornus in the plankton requires about $30 \mathrm{~d}$ (Turner 1992b). Oceanic currents in the Indian Ocean are on the order of $1 \mathrm{~m} \mathrm{~s}^{-1}$ (Deutsches Hydrographisches Institut 1960) or $\sim 2600 \mathrm{~km}$ per $30 \mathrm{~d}$. The distance from western Australia to Kenya is about $9000 \mathrm{~km}$, suggesting that dispersal from Australia is an unlikely cause for population changes in Kenya.

It is most likely that multiple factors interact to create conditions appropriate for population increases. Our study suggests that reef management (i.e. no fishing) is likely to play an important role in the intensity of these population increases. However, studies in the Mombasa MNP suggest that fishing regulations instigated at or after the time of population outbreaks may not control population increases of Drupella cornus. The Mpunguti MNP, which has light and controlled fishing, had lower $D$. cornus populations than Mombasa MNP. Yet the lack of replication of these management conditions make this conclusion tentative. Clearly the interactions between reef management, coral abundance, predators, competition among corallivores, and oceanographic conditions need to be studied in more detail before a more robust understanding of population outbreaks can be obtained. 
Acknowledgements. Research was completed while supported by grants from the East African Wildlife Society, and from The Wildlife Conservation Society through grants from the Pew Charitable Trust, the Food, Conservation and Health Foundation, Grant No. HRN-5600-G-2050-00, Program in Science and Technology Cooperation, Office of the Science Advisor, U.S. Agency for International Development. Research clearance was granted by Kenya's Office of the President and logistic support was provided by Kenyan Marine and Fisheries Research Institute and Kenya Wildlife Service. Thoughtful comments by S. J. Turner, R. L. Cumming and anonymous reviewers improved the manuscript

\section{LITERATURE CITED}

Abbott, R. T., Dance, S. P. (1986). Compendium of seashells. American Malacologists, Melbourne, FL.

Aronson, R. B. (1990). Onshore-offshore patterns of human fishing activities. Palaios 5: 88-93

Ayling, A. M., Ayling, A. L. (1992). Preliminary information on the effects of Drupella spp. grazing on the Great Barrier Reef. In: Turner, S. J. (ed.) Drupella cornus: a synopsis. Department of Conservation and Land Management, Como, Western Australia, p. 37-42

Boucher, L. M. (1986). Coral predation by muricid gastropods of the genus Drupella at Enewetak, Marshall Islands. Bull. mar. Sci. 38: 9-11

Brakel, W. H. (1984). Seasonal dynamics of suspended-sediment plumes from the Tana and Sabaki rivers, Kenya: analysis of landsat imagery. Rem. Sens. Environ. 16: 165-173

Carcasson, R. H. (1977). A field guide to the coral reef fishes of the Indian and West Pacific Oceans. William Collins, London

Cumming, R. L. (1992). Interaction between coral assemblages and corallivorous gastropods on the Great Barrier Reef. In: Turner, S. J. (ed.) Drupella cornus: a synopsis Department of Conservation and Land Management Como, Western Australia, p. 43-44

Deutsches Hydrographisches Institut (1960). Atlas of Indian Ocean currents. Deutsches Hydrographisches Institut, Kiel

Glynn, P. W., Colgan, M. W. (1992). Sporadic disturbances in fluctuating coral reef environments: El Niño and coral reef development in the Eastern Pacific. Am. Zool. 32: 707-718

Hurlburt, S. H. (1984). Pseudoreplication and the design of ecological experiments. Ecol. Monogr. 54: 187-211

Kohn, A. J. (1968). Microhabitats, abundance and food of Conus on atoll reefs in the Maldive and Chagos Islands Ecology 49: 1046-1062

Lessios, H. A., Robertson, D. R., Cubit, J. D. (1984). Spread of Diadema mass mortality through the Caribbean. Science 226: $335-337$

McClanahan, T R. (1989). Kenyan coral reef-associated gastropod fauna: a comparison between protected and unprotected reefs. Mar. Ecol. Prog. Ser. 53: 11-20

McClanahan, T. R. (1990). Kenyan coral reef-associated gas tropod assemblages: distribution and diversity patterns. Coral Reefs 9: 63-74

McClanahan, T. R. (1992a). Epibenthic gastropods of the Middle Florida Keys: the role of habitat and environmental stress on assemblage composition. J. exp. mar. Biol. Ecol. 160: 169-190
McClanahan, T. R. (1992b). Resource utilization, competition and predation: a model and example from coral reef grazers. Ecol. Model. 61: 195-215

McClanahan, T. R. (in press a). Kenyan coral reef lagoon fish. effects of fishing, susbstrate complexity, and sea urchins Coral Reefs

McClanahan, T. R. (in press b). Fish predators and scavengers of the sea urchin Echinometra mathaei in Kenyan coralreef marine parks. Environ. Biol. Fish

McClanahan, T. R., Kurtis, J. D. (1991). Population regulation of the rock-boring sea urchin Echinometra mathaei (de Blainville). J. exp. mar. Biol. Ecol. 147: 121-146

McClanahan, T. R., Mutere, J. C. (1994). Coral and sea urchin assemblage structure and interrelationships in Kenyan reef lagoons. Hydrobiologia 286: 109-124

McClanahan, T R., Muthiga, N. A. (1989). Patterns of predation on a sea urchin, Echinometra mathaei (de Blainville), on Kenyan coral reefs. J. exp. Mar. Biol. Ecol. 126: $77-94$

McClanahan, T. R., Muthiga, N. A. (1992). Comparative sampling of epibenthic subtidal gastropods. J. exp. mar. Biol. Ecol. 164: 87-101

McClanahan, T. R., Shafir, S. H. (1990). Causes and consequences of sea urchin abundance and diversity in Kenyan coral reef lagoons. Oecologia 83: 362-370

Moran, P. J. (1986). The Acanthaster phenomenon. Oceanogr mar. Biol. A. Rev. 24: 379-480

Moyer, J. T., Emerson, W. K., Ross, M. (1982). Massive destruction of scleractinian corals by the muricid gastropod, Drupella, in Japan and the Philippines. Nautilus 96 $69-82$

Moyer, J. T., Higuchi, H., Matsuda, K., Hasegawa, M. (1985). Threat to unique terrestrial and marine environments and biota in a Japanese National Park. Environ. Conserv. 12: $293-301$

Nelson, J. S. (1984). Fishes of the world. Wiley-Interscience Edmonton

Osborne, S. (1992). A preliminary summary of Drupella cornus distribution and abundance patterns following a survey of Ningaloo Reef in spring 1991. In: Turner, S. J. (ed.) Drupella cornus: a synopsis. Department of Conservation and Land Management, Como, Western Australia, p. $11-18$

Randall, J. E. (1967). Food habits of reef fishes of the West Indies. Stud. trop. Oceanogr. 5: 665-847

Spry, J. F. (1961). The sea shells of Dar es Salaam: gastropods Tanzania Society, Dar es Salaam

Turner, S. J. (ed) (1992a). Drupella cornus: a synopsis. Department of Conservation and Land Management, Como, Western Australia

Turner, S. J. (1992b). The egg capsules and early life history of the corallivorous gastropod Drupella cornus (Roding, 1798). Veliger 35: 16-25

Turner, S. J. (1994). Spatial variability in the abundance of the corallivorous gastropod Drupella cornus. Coral Reefs 13 $41-48$

Wilson, B. (1992). Taxonomy of Drupella (Gastropoda, Muricidae). In: Turner, S. J. (ed.) Drupella cornus: a synopsis. Department of Conservation and Land Management, Como, Western Australia, p. 5-10

Yan, X., Ho, C., Zheng, Q., Klemas, V. (1992). Temperature and size variabilities of the Western Pacific warm pool Science 258: 1643-1644

Manuscript first received: March 17, 1994

Revised version accepted: September 14, 1994 